\title{
Survey Project on Opinion and Attitude toward Narrating News Program of People in Northern Part of Thailand
}

\author{
Wanchalee Noriya ${ }^{1}$, Oam To-aj ${ }^{2}$ \\ ${ }^{1,2}$ Faculty of Social Sciences and Humanities, Mahidol University, Thailand \\ ${ }^{1}$ wanchalee.nor@mahidol.ac.th, ${ }^{2}$ oam.deto@gmail.com
}

\begin{abstract}
The purposes of this research were to study the behavior of watching news programs of people in the northern part of Thailand, attitude towards programming and content of narrating news programs, and compare the expectations and satisfaction of people in the northern part of Thailand towards watching a narrating news program. This research is quantitative research, with a comparative study of sports and entertainment news to watch news programs using questionnaires as a research tool. The research population consists of 1,600 people living in the north of Thailand with ages 15 and above. Data were analyzed using descriptive statistics and t-test (Independent Sample t-test and Pair sample t-test). The results revealed that most of the samples used to watch narrating news program on television, both on weekdays and holidays between $18.01-21.00$ hrs which had the frequency of watching narrating news program every day. The narrating news program viewed because the language is easy to understand, and the reliability of the news programs is at a medium level. The results of the study also revealed that the sample group has an attitude towards program planning and contents of narrating news programs at a high level; the expectation was more significant than the satisfaction with the viewing of narrating news programs, which were the statistically significant difference at the 0.05 . Entertainment and sports news have different attitudes towards programming and content of narrating news programs with statistically significant at the 0.05 level $(\mathrm{P}-$ value $=0.00$ ), but the expectations and satisfaction are not different. While both types of news, sample groups were less satisfied with the narrating news programs than expected
\end{abstract}

Index Terms

Behavior of watching narrating news program, Sports news, Entertainment news

Article Received: 10 August 2020, Revised: 25 October 2020, Accepted: 18 November 2020

\section{Introduction}

In the digital era, the combination of the internet of thing (IOT) makes all technologies connected to networks with systematically for exchanging and sharing to each other both industry and business section. Furthermore, the society problem solving and how to spend the life is the reason why people has changed which is reflected by the behavior of using the internet. Especially, all the activities process has been activated through the mobile device due to the convenience, such as purchasing the product through online (E-Commerce), approaching the data, and using the social media (Facebook, Twitter, Instagram, and so on) [1]

From the behavior of using the internet of Thai people in 2019 found that Thai people used the internet (1 hour 22 minutes per day) which was longer than the previous year about 17 minutes. The behavior of using the internet for work/study (About 9 hours 52 minutes), using the internet on holiday (About 11 hours 38 minutes). (Office of National Digital Economy and Society Commission, 2019). [2] It can be seen that the pattern of watching TV program has been changed due to the variety selection, but most people are still watch the live TV program from the TV station (More than $84.90 \%$ ) which the on demand watching rate has increased more than $15.10 \%$ (Thailand National Frequency Allocation, 2019). Considering into the detail found that most people watched the news TV program.

Nevertheless, in order to open the opportunity for those entrepreneurs who want to step into the television industry, there was the setting of the first broadcasting master plan (2012-2016). [3] In the strategy 5.2 which is the strategy for the regulating of audio broadcasting and television broadcasting services, [4] the issue was the transforming from analog to digital and changing from the frequency concession to the license system. With high digital technologies cause the increasing of the TV channel, and terminated the monopoly system in television enterprise. However, the processing from the above statement affects the television entrepreneurs to focus the business factor for driving their enterprises, and it makes more competitive in the market since the principal of doing the business is advertising, and there are more than 20 channels in the digital TV. In the end, this causes the quality of TV program. All TV channels need to survive in their business, some of them might do something out of the regulations in order to convince people to watch, some of them put on the air with inappropriate content, presented the fake news (most of the fake news are the entertainment and the sport program).

The research is interested in studying and exploring the opinions of those people who watch the narrating news program. The researcher realize the importance of the region difference, so the researcher survey in the northern part of Thailand for studying the context. Because the northern part was the first region where people were getting into the elderly society, and the birth rate is at low level which will cause to the increasing of the age of dependency. In addition to, the researcher found that the family structure in the northern part has changed from extended family to nuclear family, and the size is smaller because the immigration for studying or working in the city and the divorce problem. It diminished the strength of the family institution and also lessen the role of taking care and creating the ethics for the family members. 
From those reasons, the researcher is interested in exploring the expectation and the satisfaction of people who live in the northern part of Thailand toward watching the narrating news program, and the attitude towards the TV program contents in the digital system. This study will gather the people behavior in Northern part area in the issue of watching, the news analyzing, the narrating news from each station, and the opinions toward the TV program in both moderators and the program and the fact that presents if those moderators respect the regulation of being a good mass media.

\section{Research Objectives}

To study the behavior of watching news programs of people in the northern part of Thailand.

2.2 To survey and compare the expectation and the satisfaction of people in the northern part of Thailand towards watching the narrating news program, and the attitude towards the programming and the content of narrating news program.

2.3 To compare the category of the entertainment and the sport news, the attitude towards programming and the narrating news program content, the expectation and the satisfaction from watching the narrating news program.

\section{Scope Of Study}

3.1 The scope of content: Process to survey the opinion towards watching narrating news program, and the attitude towards the program contents from people who live in the northern part of Thailand. The researcher studied in the issues which were as follows; (1To study the attitude towards the programming and the content of narrating news program. 2) To survey the expectation and the satisfaction with watching the narrating news program (3To compare the category of the entertainment news and the sport news towards programming, the content of narrating news program, and the expectation and the satisfaction with narrating news program.

2.3The scope of the population and area: The people who live in the northern part of Thailand, and the age more than 15 years old. The total number are 1,600 people.

3.3The scope of the duration: 6 months which started from February to July 2019.

\section{Methodology}

This research was the quantitative research by using the questionnaire as the tool for studying. The questionnaire was tested by IOC $(0.67-1.00)$, and Coefficient Alpha Cronbach (0.87). Then, the questionnaires were used for collecting and analyzing the data.

The population in this research are the people who live in the northern part of Thailand, and the age are more than 15 years old. The population are 18,456, 000people (The expectation of the population in the mid of 2018) (The journal of population and social research Mahidol, 2018). The researcher calculated by using the formation of Taro Yamane (1967), and the result were 400 people. However, for covering all area, the researcher decided to extent to
1,600 people in 4 provinces by using the purposive sample. (400 people per one province). The purposive sampling were divided into 4 life stages, as follows; ( 1Baby Boomer (People who were born from 1946 to 1964) ( 2Generation X (People who were born from 1965 to 1979) Generation Y (People who were born from 1980 to 1997) (4Generation Z (People who were born after 1997). The 100 sample were selected for each province. The selected were as follows; Voluntary Selection and Snowball Selection.

After the researcher received the raw data, then the descriptive statistic and the inferential statistic with t-test (Independent Sample t-test and Pair sample t-test) were used for analyzed the data.

\section{Research Results}

The result in the title of "Survey project on opinion and attitude toward narrating news program of people in northern of Thailand" can be divided into 6 parts which are as follows;

\subsection{The personal data}

The result from the 1,600 respondents found that most respondents were female (1,006 people, $62.90 \%)$. The age are in 4 life periods which are as follows; Generation BB ( 73 - 55years old), generation X ( 54 - 40years old), generation $\mathrm{Y}$ ( 39 - 22years old), and generation Z (Not over 21years old). The sample are 100 people for each life period (25\%), bachelor degree (765 people, $47.82 \%$ ), single status (814 people, $50.90 \%)$, income per month can earn from 10,30 - 001, 000baht (680 people, 42.50\%), working in the private company (438 people, $26.90 \%$ ), and most people live in the detached house (639 people, $39.90 \%$ ).

\subsection{The result of studying the behavior of watching narrating news programs}

The result of studying the behavior of watching narrating news found that most samples used to watch the narrating news program $(1,463$ people, $91.40 \%)$, and never watch (137 people, $8.60 \%$ ) respectively. Those samples who watched the narrating news program 1-2 months ago (1,320 people, $82.70 \%)$. Those samples who watched both in the weekday and in the weekend ( 677 people, $42.30 \%$ ), in the period of $00.21-01.18$ ( 430people, $90.26 \%$ ), watch everyday (627 people, $39.20 \%$ ). The category of the favorite news, as follows; the entertainment new (279 people, $17.40 \%$ ), sport news (123 people, $7.70 \%$ ), and other news, such as the international news, the criminal news, the society news, and so on $(1,061$ people, $66.30 \%)$, watch the news because the language is easy to understand (669 people, $41.80 \%$ ), watch the news in digital system (921 people, $57.60 \%$ ), and most samples believe in the narrating news in the medium rate (580 people, $36.30 \%$ ).

The behavior of watching the narrating news program in the overall picture were often $(\bar{X}=64.3, \mathrm{SD}=.(659$. The issue in the behavior level of watching the narrating news program was in top three, such as you always watch only your favorite news $(\bar{X}=91.3, \mathrm{SD}=$.(891. The second was you always do the activity while watching the narrating news program $(\bar{X}=$ 
89.3, SD = . (901. And you always alternate the channel between the narrating news program and other programs ( $\overline{\mathrm{X}}=73.3, \mathrm{SD}=$.(927. The least behavior of watching the narrating news program, such as you always watch the narrating news program if only there's someone open the channel for you $(\overline{\mathrm{X}}=54.3, \mathrm{SD}=.(019.1$.

5.1 The result of studying the level of the attitude towards programming and the content of the narrating news program

The attitude towards programming and the content of the narrating news program in overall were high $(\bar{X}=15.4$, $\mathrm{SD}=$.(467. The highest attitude were as follows; the presenting pattern aspect was in highest level $(\bar{X}=21.4$, $\mathrm{SD}=$.(536. The second highest attitude was the clearly original location identify aspect was high $(\bar{X}=19.4, \mathrm{SD}=$ .636. The attitude in term of broadcasting covering aspect was high ( $\overline{\mathrm{X}}=18.4, \mathrm{SD}=.575)$. The attitude in updating the news aspect was high $(\bar{X}=4.17, S D=.619)$. The attitude in term of the content of the narrating news program was high ( $\overline{\mathrm{X}}=12.4, \mathrm{SD}=.(593$. The attitude in term of the content in term of hitting to the point was high $(\overline{\mathrm{X}}=1.41, \mathrm{SD}=.650)$. The attitude in term of the balance and fairness was high ( $\overline{\mathrm{X}}=4.10, \mathrm{SD}=.(695$. The attitude in term of the precious news presenting aspect was high $(\bar{X}=4.09, \mathrm{SD}=.5(81$. The attitude in term of the narrating news programming was high ( $\overline{\mathrm{X}}=4.09, \mathrm{SD}=.591)$. And the attitude in term of the neutrality was high $(\overline{\mathrm{X}}=4 . / 0, \mathrm{SD}=.(695$, respectively.

\subsection{The result of comparing the expectation and the satisfaction with watching the narrating news program}

The result of comparing the expectation and the satisfaction with watching the narrating news program can be shown in Table 1

Table 1 The comparison of the expectation and the satisfaction with watching the narrating news program

\begin{tabular}{|c|c|c|c|c|c|}
\hline $\begin{array}{c}\text { Watching the } \\
\text { narrating news } \\
\text { program }\end{array}$ & Mean & $\begin{array}{c}\text { Std. } \\
\text { Deviation }\end{array}$ & $\begin{array}{c}\text { Mean } \\
\text { difference }\end{array}$ & $\mathbf{t}$ & P-value \\
\cline { 1 - 3 } Expectation & 4.44 & .499 & .537 & 28.583 & $.000^{*}$ \\
\cline { 1 - 3 } Satisfaction & 3.90 & .624 & & & \\
\hline
\end{tabular}

*The significance level at 0.05

From the table 1 found that people in the northern part of Thailand had the expectation in watching the narrating news program in highest level $(\bar{X}=4.44, \mathrm{SD}=.499)$, and the satisfaction with watching the narrating news program in high level $(\overline{\mathrm{X}}=3.90, \mathrm{SD}=.624)$. The result of the comparison between the expectation and the satisfaction with watching the narrating news program by using pair sample t-test which found that people in northern part of Thailand had more the expectation in watching the narrating news program compared to the satisfaction with watching the narrating news program with statistically significant at the 0.05 level $(\mathrm{P}$-value $=0.00)$

5.5 The result of the entertainment news and sport news category with the attitude toward programming and the content of the narrating news program

The result of the entertainment news and sport news category with the attitude toward programming and the content of the narrating news program which were shown in the table 2

Table 2 The comparison between the entertainment news and the sport news with the attitude toward programming and the content of the narrating news program

\begin{tabular}{|c|c|c|c|c|c|}
\hline $\begin{array}{c}\text { Watching the } \\
\text { narrating news } \\
\text { program }\end{array}$ & Mean & $\begin{array}{c}\text { Std. } \\
\text { Deviation }\end{array}$ & $\begin{array}{c}\text { Mean } \\
\text { difference }\end{array}$ & $\mathbf{t}$ & P-value \\
\hline Entertainment news & 3.97 & .491 & .154 & 2.962 & $.003^{*}$ \\
\hline Sport news & 4.13 & .458 & & & \\
\hline
\end{tabular}

*The significance level at 0.05

From the table 2 shows the result of the comparison between the news category and the attitude toward the programming and the content of the narrating news program by using independent sample t-test found that the entertainment news and the sport news had the attitude toward the programming and the content of the narrating news program with no statistically significant difference at the 0.05 level $(\mathrm{P}$-value $=0.00)$ which the sport news had more attitude toward the programming and the content of narrating news program compared to the entertainment news.

5.6 The result of the entertainment news and the sport news category toward the expectation and the satisfaction with watching the narrating news program

The result of the entertainment news and the sport news category toward the expectation and the satisfaction with watching the narrating news program which were shown in the table 3

Table 3 The comparison between the entertainment news and the sport news toward the expectation and the satisfaction of watching the narrating news program

\begin{tabular}{|c|c|c|c|c|c|c|c|}
\hline \multirow{2}{*}{$\begin{array}{l}\text { Watching the } \\
\text { narrating } \\
\text { news program }\end{array}$} & \multicolumn{2}{|c|}{$\begin{array}{l}\text { Entertainment } \\
\text { news }\end{array}$} & \multicolumn{2}{|c|}{ Sport news } & \multirow[t]{2}{*}{$\begin{array}{c}\text { Mean } \\
\text { difference }\end{array}$} & \multirow[t]{2}{*}{$t$} & \multirow{2}{*}{$\begin{array}{c}\mathrm{P}- \\
\text { value }\end{array}$} \\
\hline & Mean & SD & Mean & SD & & & \\
\hline $\begin{array}{l}\text { Entertainment } \\
\text { news }\end{array}$ & 4.39 & 5.17 & 4.41 & .512 & .01 & 7 & 783 \\
\hline Sport news & 3.90 & .369 & 3.86 & .539 & -.037 & .566 & .572 \\
\hline
\end{tabular}

*The significance level at 0.05

From the table 3 shows the comparison between the entertainment news and the sport news toward the expectation and the satisfaction by using independent sample t-test which found that the entertainment news and the sport news had no difference in the expectation for watching the narrating news with no statistically significant difference at the 0.05 level $(\mathrm{P}$-value $=.783)$, and the people in the northern part of Thailand had more expectation with 
the sport news compared to the entertainment news. And it also found that the entertainment news and the sport news had the satisfaction in watching the narrating news program with no statistically significant difference at the 0.05 level $(\mathrm{P}$-value $=.572)$ which the people in the northern part of Thailand was more satisfaction with the sport news compared to the entertainment news.

From the table 3 found that the people in the northern part of Thailand had more expectation towards watching the entertainment news compared to the satisfaction by having the different average at 0.49 , and found that the people in the northern part of Thailand had more expectation towards watching the sport news compared to the satisfaction by having the different average (0.55) which means both two news categories show that the people in the northern part of Thailand had less satisfaction than the expectation.

\section{Discussion}

From the result in the title of the survey project on opinion and attitude towards narrating news program of people in northern part of Thailand which the researcher can be discussed as the objective which were as follows;

\subsection{The behavior of watching the narrating news of people in the northern part of Thailand}

The narrating news program is the program that presents the important event in daily life which is different from the news reporting that focus on presenting in the present news. The language needs to be short but understanding. In the mean times, the narrating news focus on using the news content for the audiences. Behavior of watching the narrating news of people in the northern part of Thailand found that most samples watch the program every day from $18.01-21.00$, and the frequency in watching the narrating news program everyday which relates with the research of Utomporn Sukwongkort (2014) [5] in the title of the behavior of accepting and satisfying toward the program on BBTV Channel, the result found that most samples watch the news at night time from 19.40 to 20.30 everyday ( 7 times/week). However, people always watch the program from Monday to Friday which reflects to the behavior of watching the news for people in the country. People always watch the news every day because they want the updating news, they are able to watch both of the news and the narrating news program. People who live in Bangkok always watch the news in the weekday night due to more distant working place or school if compares to the people who live in the northern part of Thailand. Furthermore, the result found that people in the northern part of Thailand always select only their favorite program, and doing any other activities or alternating to other channels while they are watching the narrating news program which relates to the work of Pornchai Panchaiyaphum (2016) [6] in the title of studying the behavior of watching and the satisfaction toward the narrating news program in all aspects of Modern nine TV of people in Bangkok. The result found that most people always alternate at highest level, select only their favorite program, and people expose their attitudes that the length of narrating news program is too long which they rarely watch the program to the end.

\subsection{The opinion of people in the northern part of Thailand toward the narrating news, and the attitude towards the programming and the content of the narrating news program}

The opinion of people in the northern part of Thailand toward the narrating news can be considered that if the satisfaction level with narrating news program is lower than the expectation, it will be dissatisfied, but if the satisfaction level with narrating news program is higher than the expectation, it will be satisfied. The issue about the opinion of the narrating news program relates to the pattern and the presenting method which were as follows; the correct data, the variety, the update, the period and duration of presenting, the neutral of the news program, and the news reporter factors, such as the language, the knowledge, and the ability of attracting which found that people in the northern part of Thailand had more expectation compared to the satisfaction with the statistically significant difference which relates to the work of Kallayapa Navarat (2017) [7] which found that the expectation was different with the satisfaction toward the E sport competition live of people in overall. When we considered in detail found that both the narrating news program of people in northern part of Thailand and watching E sport competition live were more expectation if compared with the satisfaction. Especially, in the aspect of the content of the program, and the moderator's expectation which was the same as the variety and updating of the narrating news program. The moderator is one of the attractive factors for satisfying with the program which the program might not be as expected because some moderators may lack of experience or knowledge.

For the attitude towards programming and the content of narrating the news program can be divided into 11 aspects which are as follows; the narrating news programming aspect, the narrating news content aspect, the correction of news presentation aspect, the news updating aspect, the balance and fairness aspect, the point hitting aspect, the neutrality aspect, the clearly original location identify aspect, the language is easy to understand aspect, the broadcasting covering and the duration aspect, and the news presenting pattern aspect. The result found that the attitudes toward programming and the content of narrating news program were at the highest level, such as the presenting pattern was in the highest level, and the second highest were the clearly original location identify aspect and the broadcasting covering and the duration aspect which relates to the work of Sunsinee Chaiprasert (2016) [8] which studied the news program administration of digital TV for the competition found that the news program administration is still focus on the concept about the reporter role with the hitting to the point presenting pattern, quickness, accuracy and update. The additional observation about the news survey issue, the traditional way to survey the news was on the reporter, but it has been changed these days because of the updated technology. Furthermore, the news programming planning from in term of considering from the people behavior in their routine and the period of watching the main news which relates to the people attitude the news programming and the content of narrating news. 
6.3 The comparison of the entertainment news and the sport news toward the news programming and the content of narrating news program, the expectation and the satisfaction with watching the narrating news program

The news classification found that the entertainment news and the sport news is the soft news which means those news focuses on the entertainment news (Movie news, actors news and radio news), in the meantime, the sport news focuses on the sport event (The information of the event both before and after the competition.)

The result found that the entertainment news and the sport news had the attitude toward the news programming and the content of narrating news program with the statistically significant difference at 0.05 (P-value $=0.00$ ). It can be described that the news presenting focuses on the accurate presentation compared to the opinion, news details are more important than blaming someone. However, in the narrating news program presents the news with accuracy and fact rather than expose the personal comment. Moreover, many programs insert the personal comment in order to add the pleasure for people who watch the program which doesn't affect to the news victims, so it is definitely reflected by the study result that the sport news had the better attitude towards the news programming and the content of narrating news program than the entertainment news.

The entertainment and the sport news had the expectation in narrating news program with no statistically significant difference at $0.05(\mathrm{P}$-value $=.783)$. People in the northern part had more the expectation for the sport news if compared to the entertainment news, and found that the entertainment and the sport news had the satisfaction with the narrating news program no statistically significant difference at $0.05(\mathrm{P}$-value $=.572)$. People in the northern part had more satisfaction with the sport news if compared to the entertain news which relates to the news explanation of the work from Pattira Teesawat (2013) [9] which explained that the soft news is the news that focus of the entertainment incident which is easy to understand and relax, such as the society news, the entertainment news, and the sport news.

Therefore, the expectation with the narrating news program and the sport news are not different because they are in the same category. The people have the same expectation, however, when considered into the details found that people in the northern part had more expectation with watching the narrating news program and the sport news if compared to the satisfaction. It can be concluded that both two news category, the people in the northern part had less satisfied in watching the news than expected which is not related to the work of Kultida Srisamut (2015) [10] which studied in the title of the expectation the accepting behavior and the satisfaction of people in Bangkok toward LINE TV application, and found that the result of comparing between the expectation and the satisfaction from accepting the LINE TV application was statistically significant difference at 0.05 which the average level of the satisfaction was higher than the expectation from accepting the LINE TV application. Watching the narrating news program, the entertain news, and the sport news is the reporting that need focus on the news reporting ethics while most programs in
LINE TV application are the entertainment programs, such as the TV series and show TV program which are more likely to have the variety patterns and attractiveness that make people to more enjoyable and satisfying than they expected

\section{The Suggestion From The Research Result}

7.1 From the result found that people in the northern part of Thailand had the attitude toward the news programming and the content of narrating news program in the neutrality at the least level, so the related organization should examine the content of the TV station. They should give the important to the accurate presentation, not to expose the personal comment for confusing with the fact, not to distort the data, present the news with the neutrality which will be the benefit to people.

7.2 People in the northern part had satisfaction with watching the entertainment news and the sport news less than expected. Therefore, the narrating news program should have the interesting pattern. It may use the program pattern, or using the expert in each department. Especially, the moderator, the station policy, and the officers will affect to the point, or the viewpoint that will be more benefit for the people who watch the program that any other programs, such as using the audio and visual equipment for presenting the news, or using the info-graphic or online platform in the cartoon pattern which is easy to understand.

7.3. In the content of narrating news program presentation always bring the data from online media, such as Youtube, Facebook, and Instagram etc. Therefore, the news program should aware of presenting the news or believing the news from the online media which is the new sources was clear becaue to the people's attitude that identify the clearly original news was in high level.

\section{References}

[1] Devereux, E. (2007). Understanding the media. (2nd ed.). London: SAGE.

[2] Office of National Digital Economy and Society Commission. (2019). The document of declaring the result of surveying the internet users' behavior in 2019. Retrieved on December 4, 2019, from https://www.etda.or.th/publishingdetail/thailand-internet-user-behavior2019-slides.html

[3] Broadcasting and Television Businesses Act B.E. 2551. (2008). The government gazette No.125 chapter $42 \mathrm{~A}$.

[4] National Broadcasting and Telecommunications Commission (NBTC). (2019). The survey of the behavior and the trend of watching motion media of Thai people in 2019. Retrieved 
on December 4, 2019, from http://www.nbtc.go.thgetattachment/News/ Information/

$39402 /$ ติกรรมและแนวโน้มการรับชมทีวีฯ..pdf.aspx

[5] Utomporn Sukwongkort. (2014). The behavior of accepting and satisfying toward the program on BBTV Channel 7. Retrieved on December 4, 2019, from https://www.spu.ac.th/commarts/files/2014 /06/บทความวิชาการ 11 พค.pdf

[6] Pornchai Panchaiyaphum. (2016). The study of the behavior of watching and the satisfaction toward the narrating news program in all aspects of Modern nine TV of people in Bangkok. Master of communication art, Dhurakij Pundit, Bangkok.

[7] Kallayapa Navarat. (2017). The expectation of the acception and satisfaction towards the E-sport live competition. Thesis of Master of Arts program in mass communication administration, Thammasart University, Bangkok.

[8] Sunsinee Chaiprasert. (2016). The news program administration of digital TV for the competition. Independent study of Master of Arts program in mass communication administration, Thammasart University, Bangkok.

[9] Pattira Teesawat. (2013). The analyzing of the communication model for driving the Thai newspaper innovation. College of social communication innovation, Srinakharinwirot University, Bangkok.

[10] Kultida Srisamut. (2015). The expectation the accepting behavior and the satisfaction of people in Bangkok toward LINE TV application. Master of Arts program in mass communication administration, Thammasart University, Bangkok. 